TERESA GRZYBKOWSKA

\title{
The Pseudojapanese in "Young Poland" Art
}

Japanese art was for the first time presented outside Japan in 1862 at the London World Exhibition, and then in Vienna in 1873 and Paris in 1878 with the cooperation of an outstanding connoisseur, Wakai ${ }^{1}$. To European artists it was a true revelation owing to its simplicity, frankness, and close contact with everyday life, but also to certain subtle features which were not easily comprehensible. In any case, it gave a strong impulse to sweep out of the European house stale academicism, historical motifs, or pretentious fables concerning the East.

Admiration and imitation of Japanese culture and art, Nipponism, was born in Western Europe and was entirely a product of Western thought. Primarily it was based upon tourists, not very numerous in that period, returning from these distant and exotic islands. This new interest and fashion developed above all in Paris and London, incited by the above mentioned exhibitions. Polish Nipponism, the main subject of this paper, also originated in Paris, the city which was the most powerfurl source of inspiration for the Polish artists active at the end of the 19th century, the "Young Poland» artists.

In general, the oriental interests of the 19 th century were inherited from previous ones, particularly from the 18th century, being a manifestation of European domination, when all 1973 other cultures were considered as subordinated and secondary ${ }^{2}$. "The Oriental World" in the 19th century European mind was entirely a romantic and passionate dream woven of poetry, literature, and art, from the writings of Byron, Flaubert, Nerval, and Lamartine, and from the paintings of Delacroix, Gérôme, and Ingres. The Orient was associated above all with Morocco, Algeria, Egypt, and Turkey, but also with Persia and India, as lands promising fabulous riches, unlimited luxury, forbidden eroticism, and hazardous adventures. Such an imaginary Orient offered satiation of those desires which were stifled by Christian morality, and it also constituted a sphere of liberty mainly appreciated by artists and their hangers-on, who lacked creative talents but were wealthy enough to make an art of life itself. For this purpose the Orient could provide a strong base and attractive accessories.

A quite different role was assigned to Nipponism. In fact it influenced the metamorphosis of European art in the last decades of the 19th century, showing new paths of development. It was also of help to many scholars, critics, and collectors of art in their search for identity. Now, to a certain extent, these replaced the old travellers, explorers, merchants, and missionaries. However, the growing knowledge of Japan was not equivalent to the full comprehension of exotic culture

${ }^{2}$ E. W. Said, Orientalism, ed. Vintage Books, New York 1978. 


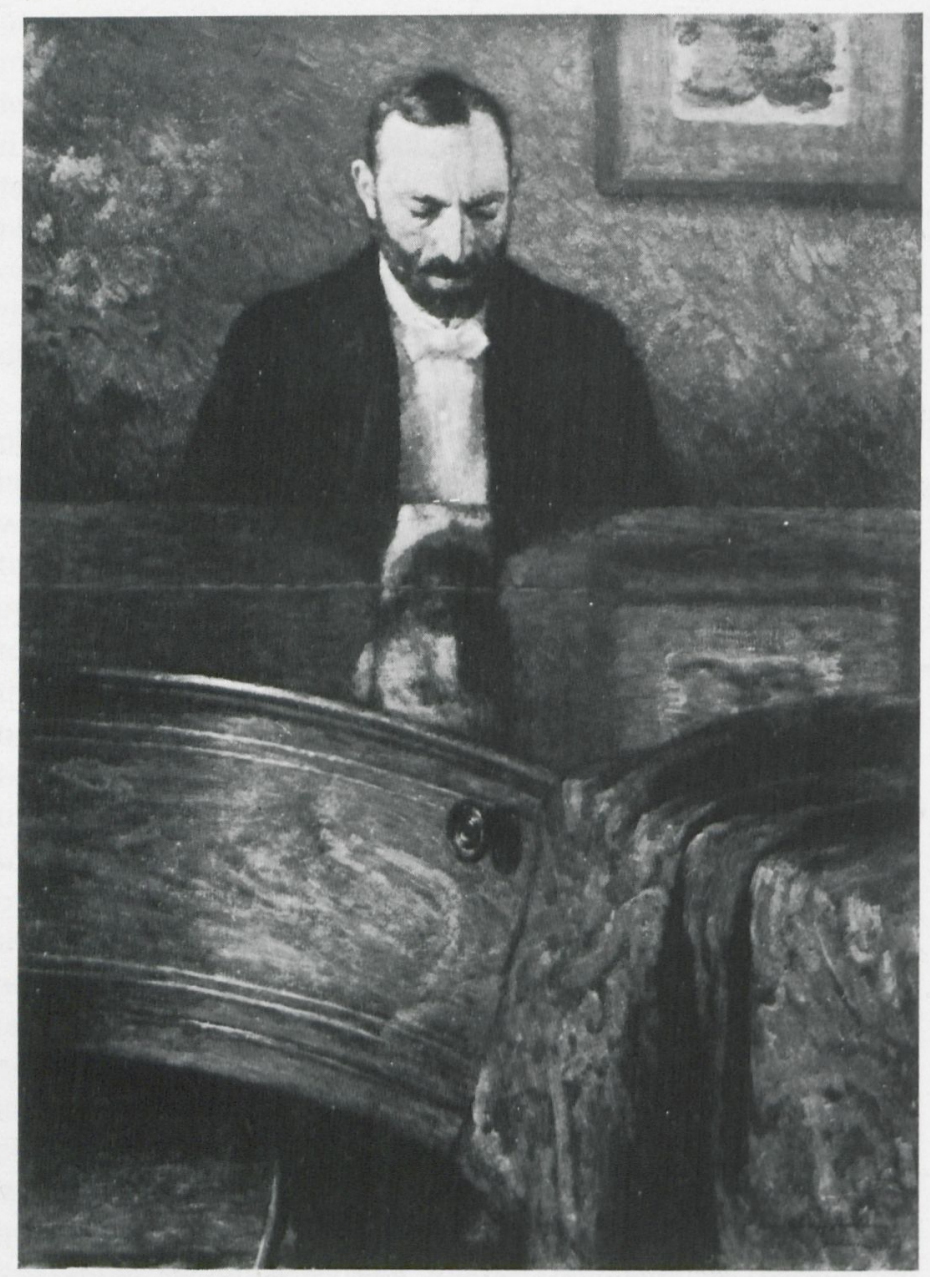

1) J. Pankiewicz, «Feliks (Manggha) Jasieński at the Piano», painting, 1908. Muzeum Narodowe w Krakowie (National Museum, Cracow).

and it did not guarantee any substantial changes in Western culture. These came much later, almost in our own times. Polish artists encountered Nipponism in the eighties and nineties of the last century in Paris (S. Wyspiański, J. Mehoffer, L. Wyczółkowski, and J. Pankiewicz), in Munich (O. Boznańska), and in St. Petersburg (F. Ruszczyc), but only a few, such as J. Fałat (in 1885) and K. Frycz (in 1920) visited Japan in person. A strong Japanese inspiration is, however, to be found in the works of graphic artists submitted to the elegant Warsaw periodical "Chimera», founded in 1901 (E. Okuń, S. Dębicki, J. Stanisławski, and others). Without any doubt the main promoter of this movement was Feliks "Manggha» Jasieński, an essayist, art critic, and collector ${ }^{3}$, [Fig. 1-3].

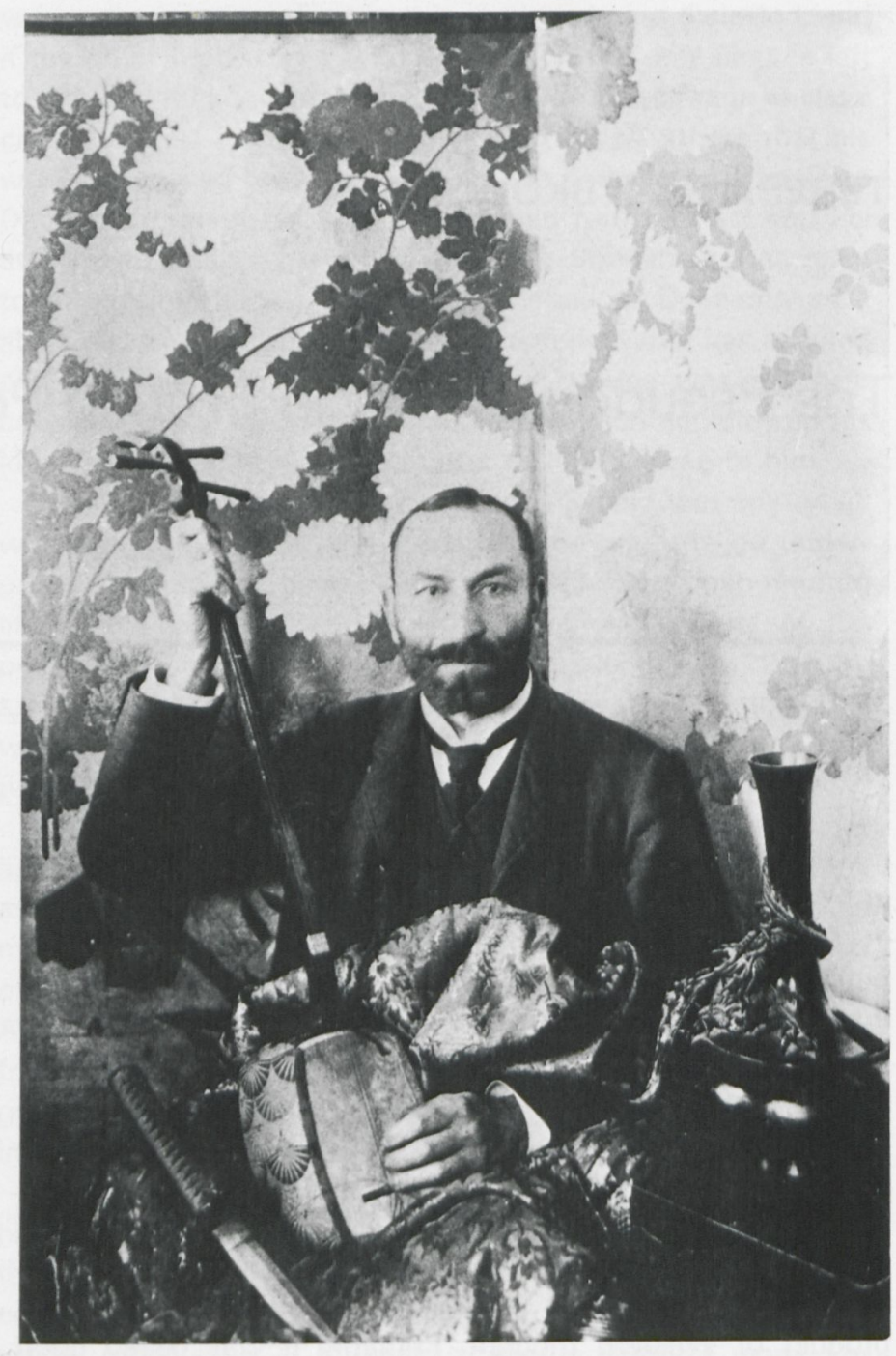

2) Feliks (Manggha) Jasieński with objects of his collection. Photographed about 1905. Muzeum Narodowe w Krakowie (National Museum, Cracow).

${ }^{3}$ So far there has been no extentive monograph devoted to $F$. Jasieński, only biographical notes and concise characteristics in some lexicons, such as J. Wiercińska, "Feliks Jasieński (Manggha) jako działacz artystyczny i kolekcjoner" (His Artistic and Collecting Activity). In: Polskie życie artystyczne 1890-1911 (Polish Artistic Life 1890-1911), ed. A. Wojciechowski, Wrocław-Warszawa-Kraków 1967, pp. 212-214, or Z. Alberowa and C. Bak, s.v. "Feliks Jasieński". In: Polski Słownik Biograficzny, vol. XI/I, 48, Wrocław-WarszawaKraków 1964. 


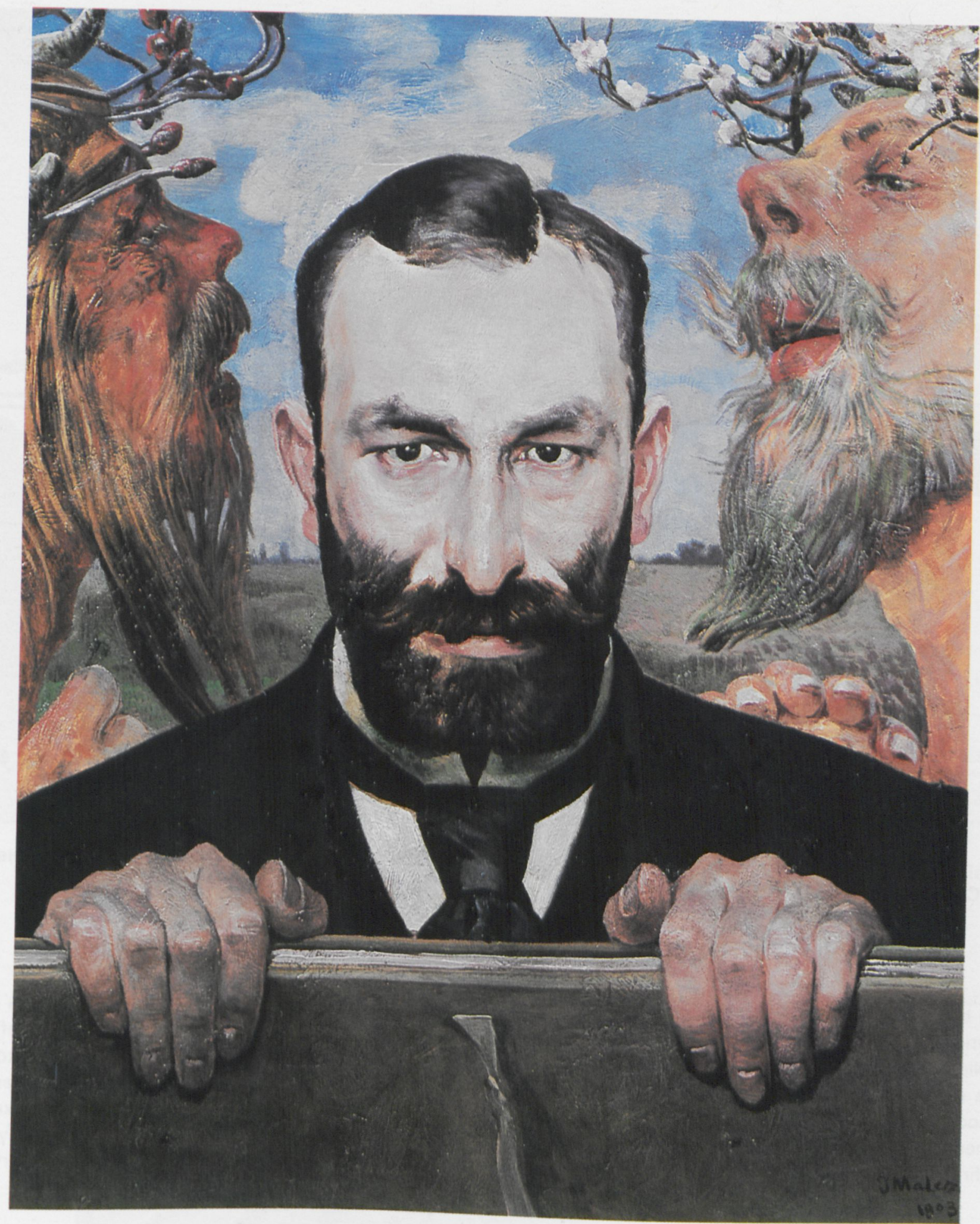
3) Jacek Malczewski, "Portrait of Feliks (Manggha) Jasieński», painting, 1903. Muzeum Narodowe w Krakowie
(National Museum, Cracow. Photo: Stanisław Michta). 


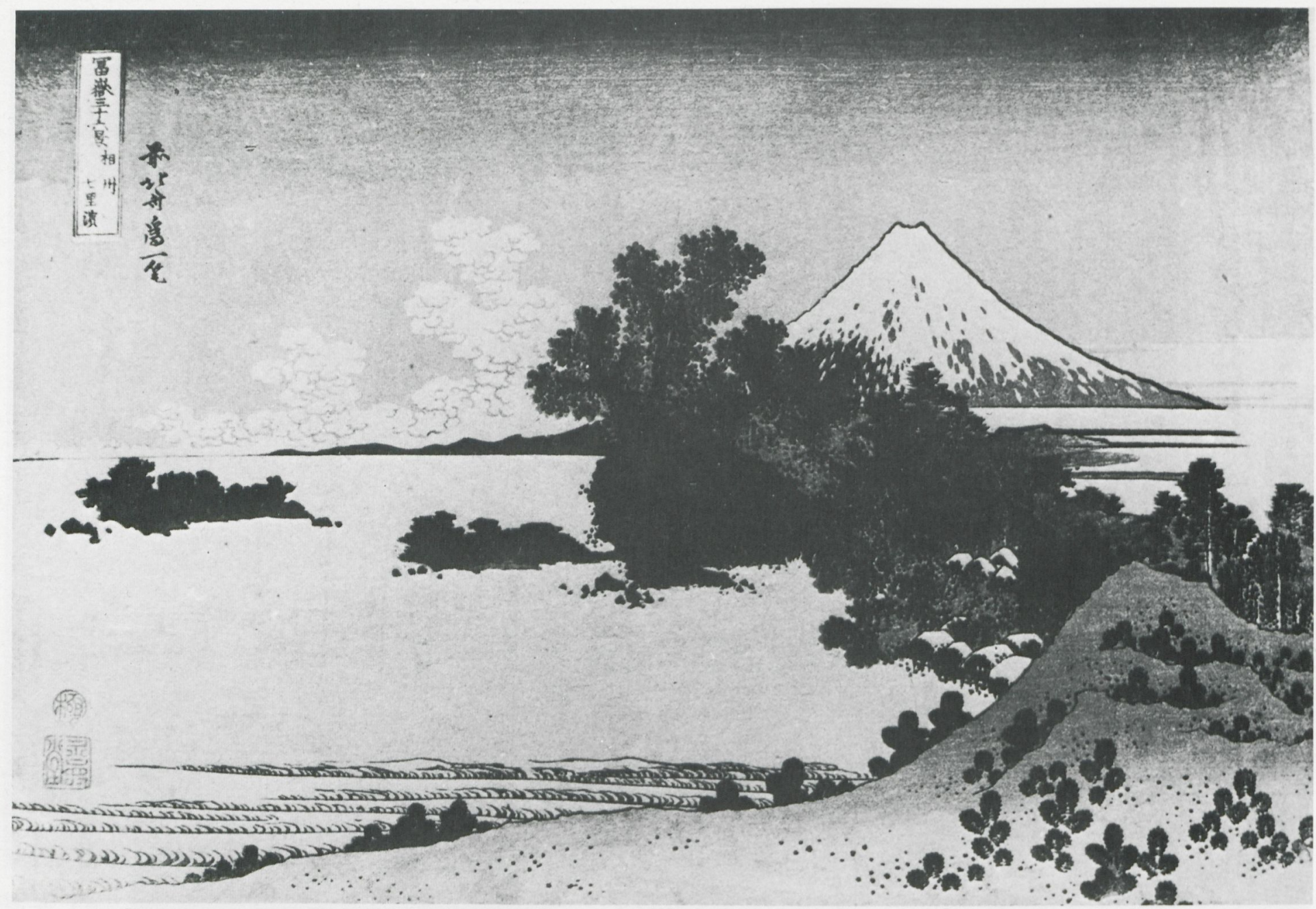

4) Hokusai, "A View of Fuji», woodcut from the Jasieński Collection. Museum Narodowe w Krakowie (National Museum, Cracow. Photo: Ryszard Kubiczek, Cracow).

Fascinated by all trends of modern art concentrated in Paris, Jasieński tried to adapt them to Poland, in keeping with the newborn Nipponism. During a fairly long stay in Paris in the eighties he started to purchase fashionable Japanese woodcuts and soon succeeded in gathering a great number, about 4600 of them, mainly the ukiyo-e class of the late Edo period, from the first half of the 19th century. Among others he

4 It is worth adding that Jasieński wrote memoirs in French, published in Warsaw in 1901 under the title "Manggha", in nine volumes. Influenced by the Goncourts, he documented all that seemed owned more than 2000 woodcuts by Hiroshige [Fig. 10-11], and also several illustrated books, with a set of illustrations called "manggha" by Hokusai, from which he took his nickname ${ }^{4}$. Apart from these, he collected Japanese ceramics, textiles, Kimonos, arms and armour, lacquer boxes, and ivory «netsuke» figures. This rich collection was finally bequeathed to the National Museum in Cracow and has survived almost

to him important in an unbroken stream of consciousness, without chapters, in an original form, 20 years before Joyce, relating his travel adventures, reading, dining, love, music, poetry, and landscapes. 


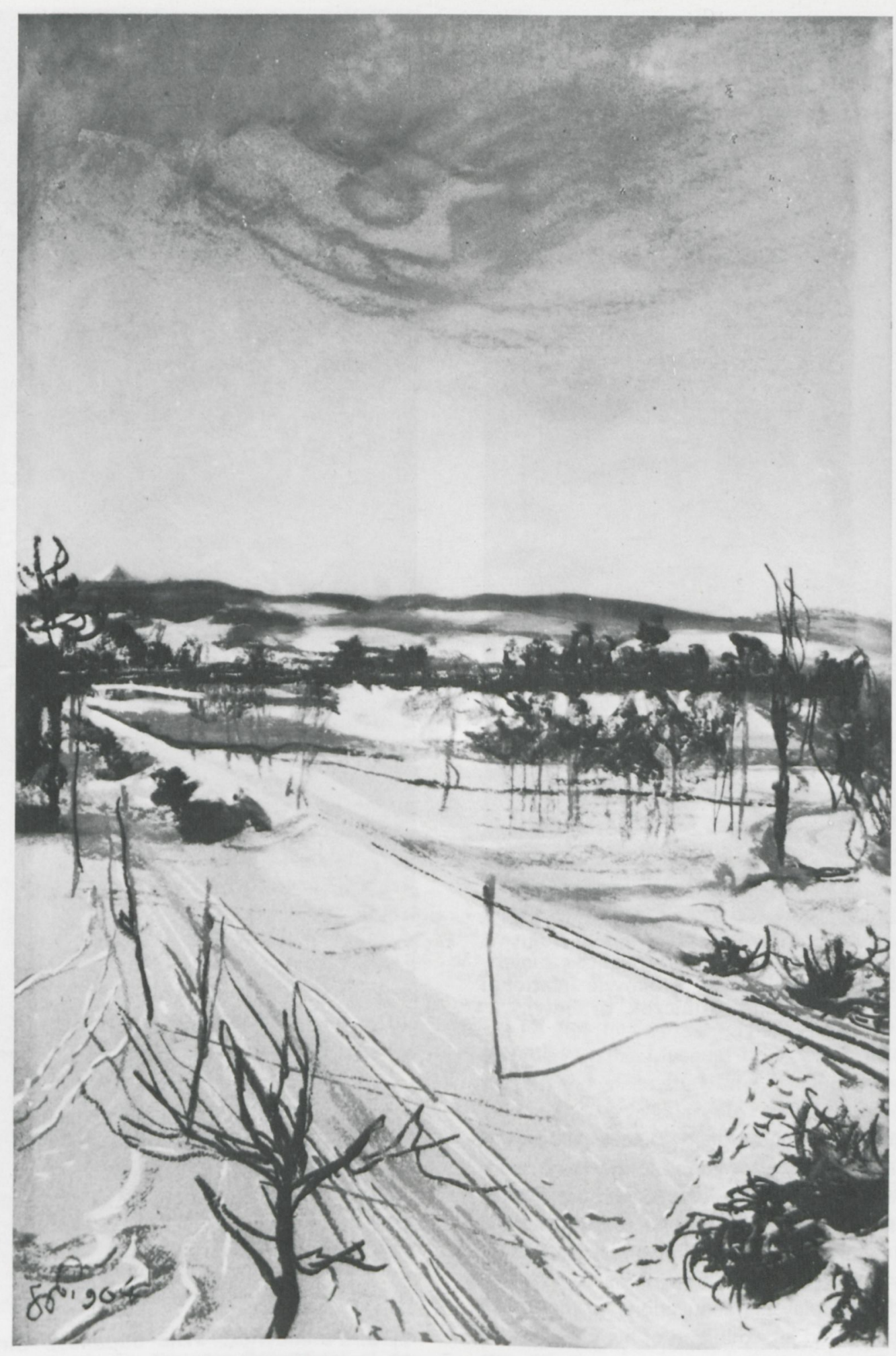

5) S. Wyspiański, "View of the Cracow Common», painting, 1904. Muzeum Narodowe w Krakowie (National Museum, Cracow). 


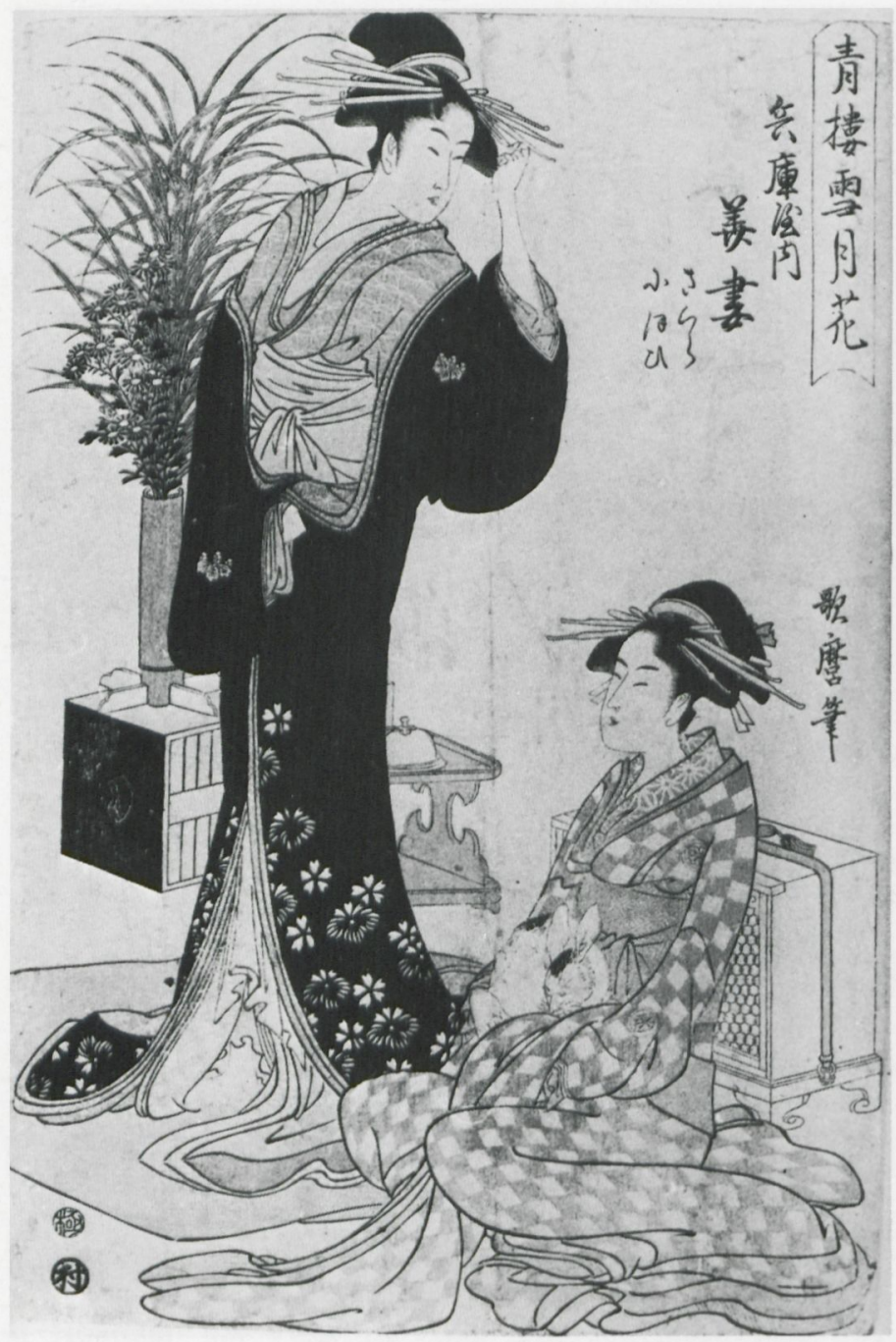

6) Utamaro, "Two Courtesans», woodcut from the Jasieński Collection. Muzeum Narodowe w Krakowie (National Museum, Cracow. Photo: Ryszard Kubiczek, Cracow).

intact, deprived, however, of some masterpieces pillaged by the Nazis in the time of World War II.

It should be added that Jasieński also acquired in Paris a number of contemporary works by French graphic artists, attracted by their freshness and the antihistorical tendencies in them, immediately after his return from Paris to Warsaw Jasieński attempted to display his acquisitions to the Polish public. In 1901 he organized an exhibition of his collection in the building of the "Fine Arts Society» in Warsaw, but it was not well received by unprepared visitors and jealous critics.

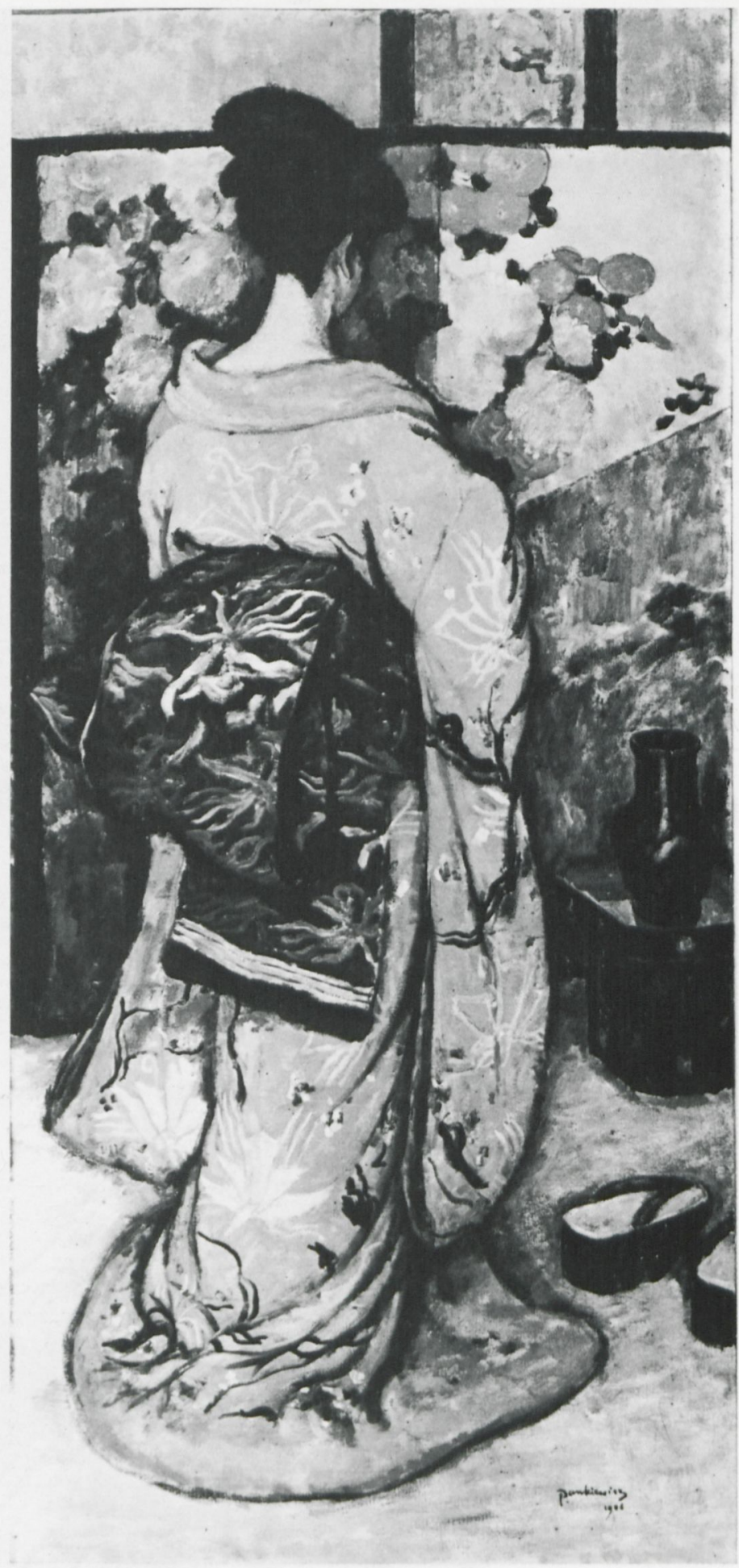

7) J. Pankiewicz, «The Japanese Girl», painting 1906. Muzeum Narodowe w Krakowie (National Museum, Cracow). 


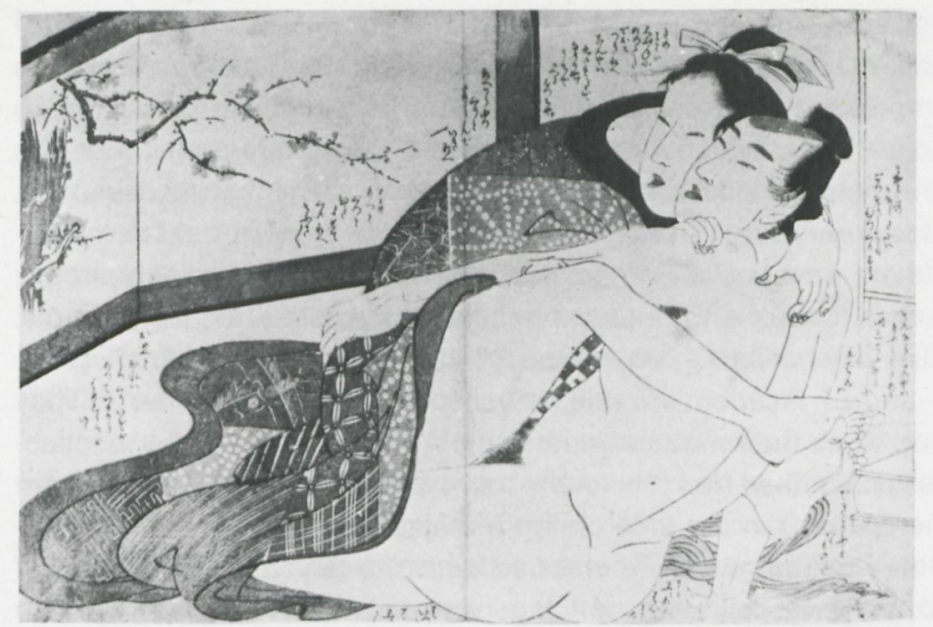

8) Utamaro, "Lovers», woodcut from the Jasieński Collection. Muzeum Narodowe w Krakowie (National Museum, Cracow. Photo: Ryszard Kubiczek, Cracow).

Infuriated, Jasieński blamed the ignorance of these people "who could not tell Chinese tea from Japanese art». In an atmosphere of scandal, he left Warsaw for Cracow, where his passions and quirks were fully appreciated. He entered into friendly relations with many artists and soon inspired them with fresh ideas. Still having money at his disposal, he eagerly purchased the best works of these artists and enlarged his private museum.

Jasieński's personality had been formed by French culture, especially by modern critics such as the Goncourt brothers non-dogmatic, explanatory, intelligent, and sceptical. His style of collecting was also French, based on the collector's predilection, similar to the one collection started in 1879 by Emil Guimet in Lyon, and then in Paris, ending up as one of the world's most collections of Asiatic art, finally left to the nation as the Musée Guimet.

It was in collecting that Jasieński, originally a writer and critic, found his fulfillment. For its sake he tried to adopt some experimental and scholarly methods, first of all founding a reference library. He spared neither time nor money in displaying his Japanese treasures around the country with lectures and discussions. He was unable, however, to consider Japan-

5 F. Jasieński, Przewodnik po dziale japońskim oddzialu Muzeum Narodowego (A Guide through the Japanese Department of the National Museum), Kraków 1906.

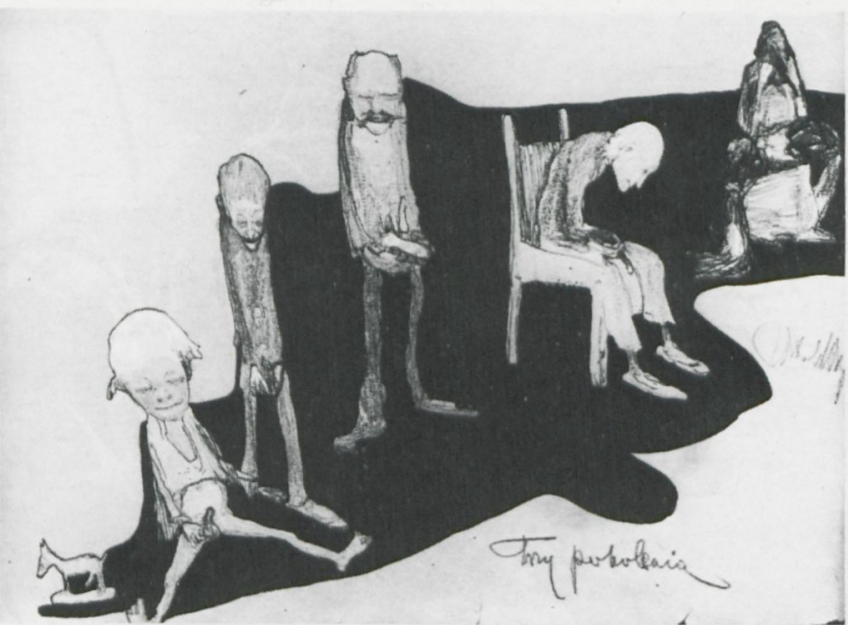

9) W. Wojtkiewicz, "Three Generations», painting, about 1905. Muzeum Narodowe w Krakowie (National Museum, Cracow).

ese art with the cold attitude of a scholar, his opinions being always perfused with emotion and rapture. He was convinced that the Japanese nation, second only to the Greeks, was one for which art was an inseparable aspect of life, Japanese art being the highest manifestation of the human spirit ${ }^{5}$. Much more sceptical and objective was a contemporary of Jasieński's, the art critic Z. Przesmycki (Miriam), the author of a study on Japan woodcuts, who strongly stressed that this art could not be fully understood by Europeans ${ }^{6}$.

Signing in 1905 a formal act of donation of his collection to the National Museum in Cracow, Jasieński expressed his aspiration that «The Japanese Museum in Cracow will be a perfect lesson for Polish artists and the Polish community». So far this has not been fulfilled as the collection was not included in the Museum until 1929, after the death of the donor, and since that time has never been fully displayed. However, we can try to analyse some of the works of Jasieński's painter friends as to their "Japanese motifs». We have an old photograph of Jasieński, standing on a balcony of his house in Cracow, wearing a kimono and sporting a samurai helmet. In another photo he is sitting proudly amidst objects from his collection [Fig. 2]. In the portrait of him

6 Z. Przesmycki (Miriam), «Drzeworyt japoński» (Japanese Woodcut), Chimera, vol. 1, 3, p. 492. 


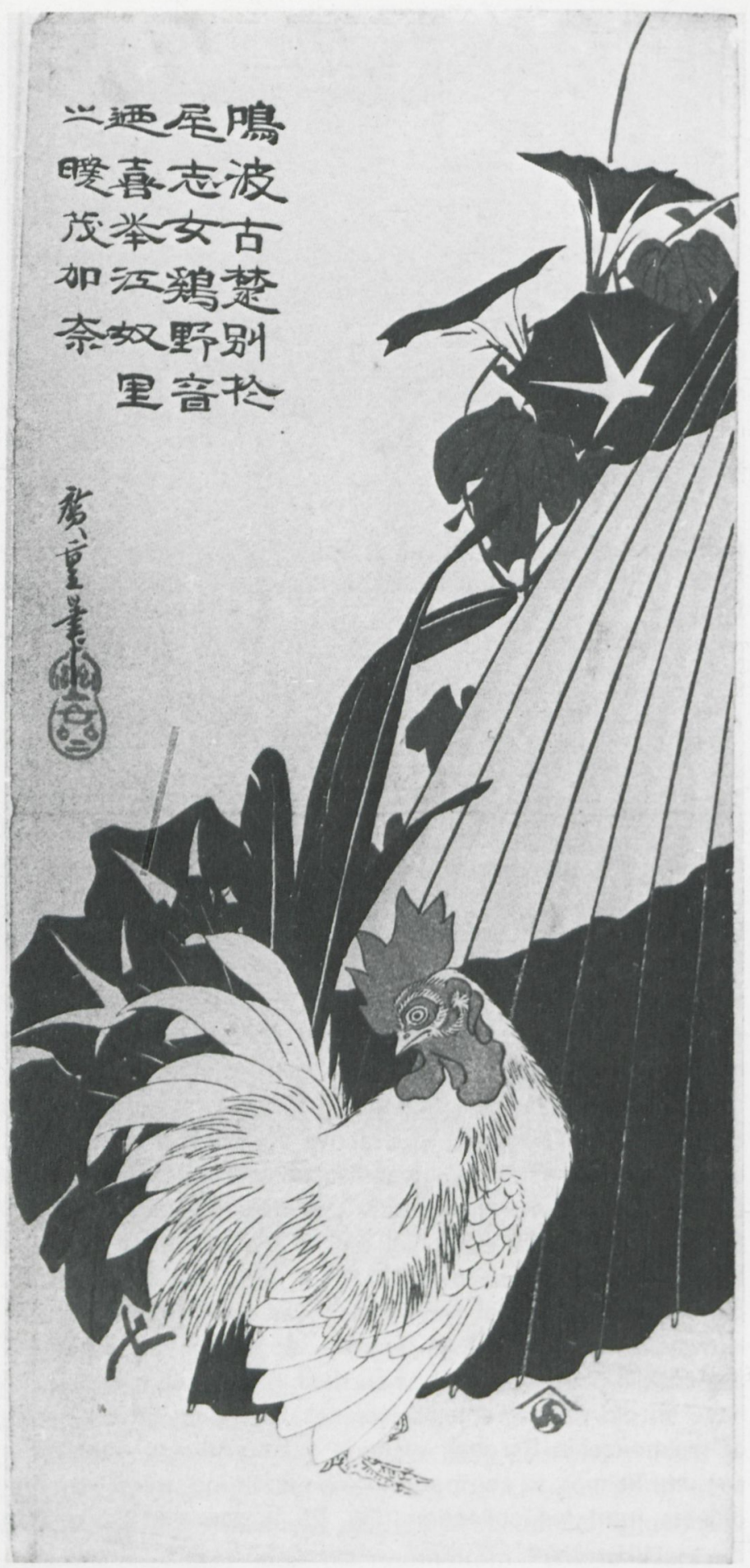

10) Hiroshige, "White Cock and a Blue Flower», ca. 1830. From the Jasieński Collection. Muzeum Narodowe w Krakowie (National Museum, Cracow. Photo: Ryszard Kubiczek, Cracow). painted by Boznańska a Japanese screen is located behind him, high on a commode, contrary to its original function. One feels the arbitrary manipulations of these objects. In all those paintings which are suspected of being created under the Japanese influence we only discover Japanese accessories, and very rarely traces of real Japanese spirit: a bold composition, unusual in Europe, for instance a bird's eye perspective or a love of emptiness, a peculiar amor vacui, as, for example, in Wyspiański's landscape of the Cracow common [Figs. 4 and 5]. Academism still prevailed in many Polish artists. They took as their models Japanese objects from Manggha's collection, as they had previously borrowed historical souvenirs from museums in the time of Jan Matejko. Moreover, these «Japanese paintings» were embued with the psychological mood of their masters, while real Japanese artists always tried to catch the essence of the universe, with total suppression of individuality. The Japanese Girl by Pankiewicz is wearing the same kimono Jasieński was photographed in, but the pattern of the fabric, of great importance to the Japanese as it shows the social rank of the wearer, is very inaccurately depicted, and so is the style in tying the obi-sash [Figs. 6 and 7]. Many other objects of the Manggha collection were assembled, without order or meaning, in these paintings. There is a general absence of Japanese contemplation of an individual object or fragment of it. The portrait of Jasieński at the piano, by Pankiewicz, in the boldness of outline approaches the compositions of Degas, but the symbol of the collector, a Japanese woodcut on the wall, is almost illegible [Fig. 1]. A "Japanese Girl» was a frequent subject for Polish painters but they were obviously Polish girls with Japanese accessories. It would also be difficult to find a close analogy between the subtle pairs of Japanese lovers in the woodcuts of Utamaro (in spite of some elements shocking to European eyes) and the sad creatures of Wojtkiewicz, lacking any power of fulfillment [Figs. 8 and 9].

A pair of unselfish lovers, whose only reason to be was to love each other with no social aspirations, was shown no trace of in Polish paintings or novels. Love was not a separate value, and a woman in love was often given the epithet of a depraved woman. Stanisław Przybyszewski who, as one of the first, introduced into Polish literature erotic motives identified passion with demonism. As in life in Polish art models of good mothers, sisters or wives prevailed. It was no different with Polish modernists - the Young Poland artists - bohemian, who always preferred to paint their wives and children; see for example the works of Mehoffer and Wyspiański. Jacek Malczewski again was first in expressing erotic visions but only in allegories and symbols. Polish art was unable to produce images of sensitive and sincere lovers such as were 
displayed by Japanese artists. Dominating Catholicism and bourgeois prudery influenced even the greatest artists and they could not manage to call happiness the human relations which were not consecrated by law and sacrament. This taboo could not be broken. Eroticism which always fascinated and alarmed was domesticated by jokes or scoffing. The intimate and deeply emotional quality of a close knit Japanese couple had a Polish counterpart in Wojtkiewicz's "Three generations», a satirical picture of impotence, unhappiness, obsession, illness, and lack of love.

For Polish artists a line had quite different aesthetic functions, tending toward expression and not to contemplation, causing explosion and not relief. Why was Japanese art too difficult to understand and imitate? The secret lies in an absolute discipline of forms, in a ruthless overpowering of nature, in the building of a picture with an iron consistancy? Every object was perfectly defined, every line and every stroke of the brush was fully determined, efficient, and infallible, every artistic gesture being the result of long training of the eyes and hand. In the works of the Young Poland artists the Japanese contemplation was changed into symbolism, the aesthetic disinterestedness into philosophical propaganda. Japanese universalism and pantheism, with no distinction between an object and subject, were entirely alien to the European milieu, particularly to Polish individualists bound to expression and literary symbols. For centuries Japan has been a society of refined habits, with a love of beautiful and delicate things, with a sacred feeling towards nature. Very early the Japanese learned to create objects of unmatched perfection. Spiritually and technically it was almost beyond the possibilities of European masters to follow these examples, especially at the end of the 19th century when the gap dividing the two cultures was much greater than now. With a very serious attitude towards life and work a Japanese artist performed his actions with full reverence, taking responsibility for all new "beings» being issued from his hands. These actions were supported by moral considerations, the concentration of mystic forces, meditation and harmony, joy of creation, and modesty as well. There was also a striking difference between the Japanese and European feelling of time. Japanese art was created in a mythical time, an everlasting present ${ }^{8}$. On the

A. W. Watts, The Way of Zen, New York 1964; Yasuichi Awakawa, Die Malerei des Zen Buddhismus. Pinselstriche des Unendlichen, Wien u. München 1970 (Deutsche Übersetzung von Dorothea Javorsky, Wien).

8 M. Eliade, The Sacred and the Profane, New York 1959, and the same author, Myth and Reality, New York 1963.

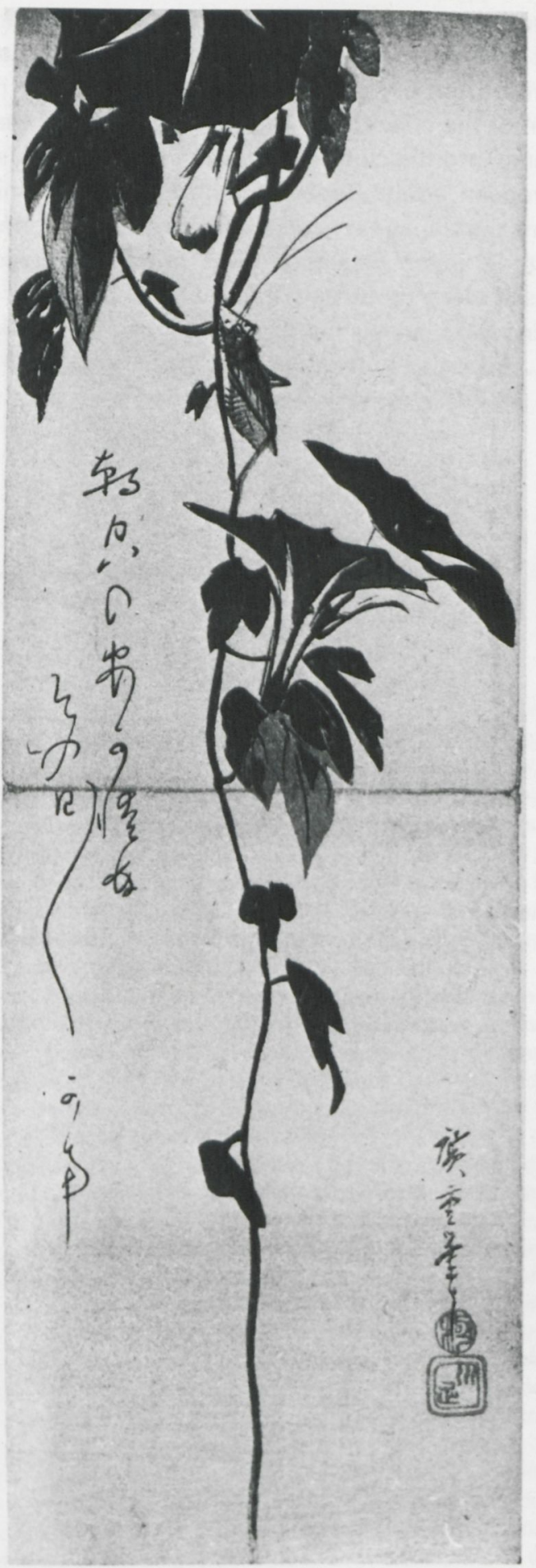

11) Hiroshige, «Flowers», ca. 1830-1840. From the Jasieński Collection. Muzeum Narodowe w Krakowie National Museum, Cracow. Photo: Ryszard Kubiczek, Cracow). 
other hand, at least from the 18th century, European art was involved in strictly historical time. In Japan even nature was considered to be a work of art, every fragment of it being a paradigm of the cosmos. In Europe the divinity of the cosmos was diluted into the cult of art for art's sake. And this explains why European artists, together with Polish modernists, took over from the Japanese works only their outer form, without feeling their inner meaning. Even more paradoxically, the modernists were motivated mainly by a negation of reality and their works were intended to express existential, social, political, and artistic revolt. Unfortunately they did not realize that the Japanese artists were in full harmony with the world and the only beings they were trying to change were themselves, in the pursuit of perfection.

Feliks Jasieński used Japanese art as a remedy for European vices and dreamed of a Japanese lesson for Polish artists. This was an illusion. They were unable to apprehend a life without history and nature as a part of the universe; above all they could not understand the ethos of the samurais, which was still alive in the far off islands. In spite of all their protests and ferment, they still lived according to bourgeois beliefs and rules, as did the French artists and those of many other European countries. 